\title{
Normative Differences in Chinese and European Discourses on Global Security: Obstacles and Opportunities for Cooperation
}

\author{
Salvatore Finamore ${ }^{1}$ (D)
}

Received: 1 August 2016/Accepted: 9 January 2017

(c) The Author(s) 2017. This article is published with open access at Springerlink.com

\begin{abstract}
This article attempts to provide an answer to the puzzle of how to account for the variations in levels and effectiveness of security cooperation between the EU and China, particularly given the apparently structural nature of the main factors affecting their security relationship. The hypothesis put forward in this study is that normative differences and overlaps could hold explanatory value in this regard, on the basis of theoretical premises grounded in social constructivism. To this purpose, the article contributes a detailed discussion of the normative positions held, respectively, by the EU and China, particularly with regard to definitions of threats and priorities, positions on national sovereignty and non-interference, and views on multilateralism and multipolarity. The impact of these normative positions is illustrated and discussed with reference to some salient cases of EU-China security cooperation, such as the Iranian nuclear issue, the ratification of the CTBT, and antipiracy operations in the Gulf of Aden. While underlining the importance of norms as an explanatory variable, the article also points to the relevance of the interplay between norms and interests, as well as their interaction with other structural factors-particularly the role of the United States as the main security actor in international affairs.
\end{abstract}

Keywords EU-China relations · Multipolarity - Multilateralism ·

Non-interference $\cdot$ Security $\cdot$ Sovereignty

Salvatore Finamore

salvatorefinamore@yahoo.it; sf403@cam.ac.uk

1 Department of Politics and International Studies, University of Cambridge, Cambridge, UK 


\section{Introduction}

China's role in international security has undoubtedly grown over the past decades, to the point where Beijing has become an unavoidable partner in any matters of global concern. While in 1999 Gerald Segal could still ask whether China mattered from a military point of view (Segal 1999, p. 29), the answer to that question would appear obvious nowadays. China's military expenditure accounted for only $4.5 \%$ of global defence spending in 1999. Rising steadily on par with China's impressive economic growth, that figure reached over $12 \%$ in 2014 according to SIPRI estimates (Perlo-Freeman et al. 2015, pp. 2-3), ranking Beijing at the second place for highest military expenditure after the United States and with an ever growing defence budget. As the European Commission noted already in its 1995 Communication A long term policy for China-Europe relations, it is "impossible to address the central global issues" of our time without China's cooperation: "China is not only a nuclear power and a permanent member of the UN Security Council, but also one of the world's biggest arms producers and exporters. Her role across the whole security spectrum is central to global, as well as regional security" (European Commission 1995).

In spite of the importance the EU attributes to China in global security, there seems to be a widespread scholarly perception that "in comparison with the political and economic relations between China and [the] EU, the relations in the field of conventional security are both relatively insignificant and complex" (Wang 2011, p. 37). While security in general may be safely regarded as a relatively underdeveloped field of cooperation in EU-China relations, it is also necessary to consider the variations which may be observed in specific instances, and attempt to explain them. There are at least three factors which have been explored in the academic literature and which can easily be argued to have a strong impact on EUChina security cooperation.

The first factor to be considered in this regard is that EU decision-making on matters of security and defence is largely conducted according to intergovernmental procedures which leave little room of manoeuvre for supranational institutions. EU member states have retained a significant margin of autonomy and decisional power in this issue area, instead of delegating it to the supranational authority of the European Commission. The Council of the European Union and the European Council are the key actors in this field, "with the main powers remaining in state hands" (Keukeleire and Delreux 2014, p. 157). Although several studies point to a gradual move away from pure intergovernmentalism (e.g. Howorth 2012; NorheimMartinsen 2010; Sjursen 2011), the level of integration within this policy area is still not comparable to the delegation of sovereign powers to which the member states have agreed on other subject matters. This would expectedly result in increased difficulties for the European Union to speak with a common voice to Beijing on issues of international security.

A second factor which can be expected to influence security relations between the EU and China is the relative distance between the two, resulting in the fact that European and Chinese primary geostrategic interests have few areas of overlap or 
conflict. The European Commission's 1994 Communication Towards a new Asian strategy points out that the "maintenance of peace and stability in Asia is an important factor not only for the protection of the Union's interests in this region [...] but also for the respect of international obligations and agreements on which the Union itself depends for its security" (European Commission 1994). At the same time, it should be noted that the EU has "no major deployments in East Asia, and no existing strategic interests" that could complicate relations with Beijing (Stumbaum 2011 , p. 8). While on the one hand this means that there may be fewer points of attrition between Europe and Beijing, on the other hand it also relegates Europe to a marginal position within China's security thinking, compared to the US or to its regional neighbours. ${ }^{1}$

The role played by Washington in particular is a third important factor which bears on EU-China security relations. As recognized by the European Commission, "from a security viewpoint the US remains the key player in the region and the current situation is characterised by a web of bilateral security arrangements between the United States and a number of Asian countries. At the present moment, no single Asian country or outside power appears to be in a position to take over the role of the US" (European Commission 1994). This evaluation still rings true in spite of China's rise, especially in light of the Obama administration's attempts to "pivot" US foreign policy towards East Asia-successfully or otherwise (cf. Campbell and Andrews 2013; Zakaria 2015) — and even though it is still too soon to predict the impact of a Trump presidency on the region. The role played by Washington is particularly important in view of the fundamental differences between the EU and the US in their security outlook towards China (cf. Finamore 2014, pp. 110-111).

While both the EU and the US share similar goals with regard to East-Asian stability and China's integration into a peaceful global order, they differ on "the question of how these goals can be best achieved" (Gill 2010, p. 261). Whereas the United States maintains a complex network of crucial political and military alliances around China's periphery, Europe has no such strategic commitments. This key difference arguably accounts for the divergences between the US and the EU, whereby the former is more likely to see China "as a traditional power projection threat", whereas the latter is more concerned with the security problems which may emanate "from within a weak China in the form of unregulated economic practices, illegal migration, environmental degradation, an inability to stem criminal activities-including proliferation-corruption, unresponsive government, rising internal unrest, and overzealous crackdown on dissent" (Gill 2010, p. 260). Given the centrality of the US in the East-Asian security balance and the fact that "maintaining the transatlantic strategic alliance with [the] US through NATO is the cornerstone of EU security" (Wang 2011, p. 38), divergences between the US and the EU may reasonably be expected to have a negative impact on EU policies towards China with an international security dimension.

These three factors-intergovernmental EU decision-making, geopolitical distance, and the hegemonic role played by the US-appear to be structural

\footnotetext{
${ }^{1}$ Author's interview with a senior Chinese academic, Beijing, 19 July 2010.
} 
features of the EU-China security landscape. At least prima facie, they seem to act as parameters, rather than variables. This leads to a clear research puzzle: if the key factors affecting EU-China security relations are structural characteristics of the relationship, how should scholars account for variations in the level of cooperation between the EU and China on security issues? Why is it that Brussels and Beijing have been able to establish positive modes of cooperation on some security issues, but not on others? This article attempts to solve this puzzle by focusing on the role of differences and overlaps in the norms guiding the behaviour of these two key actors in international affairs. In addition to different definitions of security threats and priorities, the main points of interest in this regard lie in the norms on national sovereignty and non-interference regulating the use of force, and in different understandings of multilateralism and multipolarity. Through examples and case studies, the article also aims to show how these norms interact with the structural factors identified above to bring about their effects on EU-China security cooperation. Before entering this discussion, however, it is necessary to address some preliminary theoretical questions over the role of norms as independent variables in international security.

\section{Norms and Interests in International Security}

The role of norms and values is often sidelined in conventional realist studies of international security, following the idea that they should not be considered as independent variables shaping actors' preferences and actions, but rather as derivatives of underlying material interests. Already in 1939, Edward H. Carr borrowed the Marxist notion of "relativity of thought" to argue that "ethical standards [...] are historically conditioned, being both products of circumstances and interests and weapons framed for the furtherance of interests" (Carr 1939, pp. 67-71). Realist thinking, which has traditionally dominated the realm of international security, emphasizes the notion of national interest defined narrowly in terms of state survival, focusing on the relative distribution of power within an anarchic international system. This view, which would present the study of security as bound "to the state as a referent object of security, as well as to state sovereignty as the value to be protected" (Sjursen 2004, p. 62), portrays security as a field in which values and normative considerations should be regularly set aside in favour of power and the rational pursuit of the national interest.

The limits of this position, however, have been exposed by a literature which probably traces its main turning point to Barry Buzan's People, states, and fear (1983). By advocating the need for a broader framework of reference for security studies, Buzan's seminal work opened the way for more complex understandings of security and interests which incorporate values and norms. The impact of ideational factors on the constitution of interests was similarly recognized by subsequent authors such as David Clinton, who argued that "the overall national interest [...] depends so heavily on the society's constitutive principles" (1986, p. 501). The strongest arguments for the incorporation of ideas in the interpretation of interests, however, were probably formulated by constructivist scholars such as Jutta Weldes 
and Alexander Wendt. Taking the production of US national interest during the Cuban missile crisis as a case study, Weldes's work shows that "national interests are social constructions created as meaningful objects out of the intersubjective and culturally established meanings with which the world, particularly the international system and the place of the state in it, is understood" (1996, p. 280). Similarly, Wendt argues that ideas should not be regarded simply an alternative explanatory factor in addition to power and interests, but rather that "ideas also have constitutive effects, on power and interests themselves" (1999, p. 114). Crucially, it should be noted that ideas do not refer only to images and interpretations of reality as it is, but also of the world as it ought to be, and as such they have a clear normative value. Legitimation is thus an integral part of the process of construction of national interests (cf. Weldes 1996, pp. 302-303).

While scholars should recognize the role of ideational factors in shaping a state's security interests, it would also be a mistake to run into the opposite fallacy of viewing interests simply as dependent on ideas. A more complex and arguably more accurate model, such as the one proposed by Bill McSweeney, recognizes the "recursive" relation between interests and identity, "following the logic of structure and agency" (1999, p. 127). According to this view, identities and interests contribute to shaping each other through a continuous process of interaction and mutual constitution. Identity is a central component of security, especially of the broader concept of "ontological security" espoused by McSweeney (1999, p. 156). At the same time, identity can be "altered, in practice, through a change in the interests which logically flow from it", and "we can be led to perceive ourselves differently [...] by the opportunities which may be offered to satisfy new interests" (McSweeney 1999, p. 167). A crucial point to be noted for the sake of this argument is that while identity and security are closely interconnected in a mutually constitutive process, they are also reliant on a previous moral choice. Moral judgement is a necessary precondition of the reproduction of definitions of security and identity through social dynamics of structuration.

On the basis of these theoretical positions, the reduction of norms and values to a by-product of material interests appears unwarranted. Normative considerations have an autonomous value in understanding a state's security policy, and they must be taken into account in their own right. It is significant that references to values and norms coexist noticeably with those to material interests in the main security documents of both the European Union and China. The European Security Strategy, for example, mentions European interests just as often as it points to values and norms, placing the need "to defend [the EU's] security and to promote its values" side by side (Council of the European Union 2003, p. 6). Similarly, many of the high-profile documents tracing China's security strategy also accompany a discourse of interests with one which emphasizes "the basic norms governing international relations" (Xi 2014), particularly those based upon the Five Principles of Peaceful Coexistence (cf. Ministry of Foreign Affairs of the PRC 2002). It seems necessary, therefore, to investigate the normative stances held, respectively, in Beijing and Brussels to shed interpretative light on their security cooperation. 


\section{Different Definitions of Security Threats and Priorities}

The end of the Cold War, and the collapse of the bipolar power structure which defined international relations for decades, brought about the need to rethink old security concepts and previous strategic approaches. This need was acutely reinforced by the shocking terrorist attacks which took place in the early years of this century, first in New York and then in Madrid and London, pushing new security issues violently at the top of the agenda. This evolving geopolitical context is reflected in the debates which took place both in Europe and in China, leading to the official formulation of new security concepts. While it is possible to identify many parallels and similarities between the positions adopted by the EU and China in the wake of those tragic events, it would be inaccurate to speak of a convergence tout court while overlooking the persistent differences between Chinese and European perceptions of security threats and their definitions of priorities and means to tackle them.

Both the European Security Strategy and China's Position Paper on the New Security Concept emphasize the role of non-traditional threats in the international security landscape, pointing out how today's threats "tend to be multi-faceted and global in scope" (Ministry of Foreign Affairs of the PRC 2002). Brussels and Beijing show similar concern for non-conventional security threats, such as terrorism, transnational organized crime or the proliferation of weapons of mass destruction. But while the European Security Strategy recognizes that "large-scale aggression against any Member State is now improbable" (Council of the European Union 2003), China's Position Paper lists non-traditional threats only "in addition to the traditional security areas like preventing foreign invasion and safeguarding territorial integrity" (Ministry of Foreign Affairs of the PRC 2002). While the European Union can be argued to have evolved into "the first truly postmodern international political form" (Ruggie 1993b, p. 140), China has remained firmly rooted within a paradigm dominated by "traditional ideas of territorial and state security" (Wong 2015, p. 5).

In contrast with the EU's aspirations to play an active role on most issues of relevance for international security, Beijing pursues a rather "more narrow security agenda" centred on traditional threats in the Asia-Pacific region (Bräuner 2014, p. 102). China's perception of regional threats to its territorial integrity is particularly related to maritime disputes with its neighbours over the East and South China Seas, and it is further exacerbated by Chinese concerns about an overbearing American presence in the area. Xi Jinping's notion of a "new type of great power relations" can be interpreted in this light as a reaction to the Obama administration's Asian pivot, and as an attempt to push the United States to recognize China's core territorial interests in its neighbourhood ( $\mathrm{Li}$ and $\mathrm{Xu}$ 2014). While regional security features prominently at the top of Beijing's security agenda, China tends to play a relatively minor role on issues of global security. When the country's immediate security interests are not under direct threat, Chinese leaders prefer "following the majority" instead of taking the initiative and playing a role of global leadership (Song 2013, 478). 
Nevertheless, Beijing recognizes the European Union as an important partner in addressing "shared human security interests", as evidenced in China's 2003 EU Policy Paper, which mentions specifically "fighting against international terrorism, promoting sustainable development, eliminating poverty, and protecting the environment" (Wong 2015, p. 1) as areas in which China and the European Union show similar commitment. The second EU Policy Paper, released in 2014, adds other key non-conventional security concerns to this list, such as cybersecurity, energy security, illegal migration and organized transnational crime (Ministry of Foreign Affairs of the PRC 2014). The extent to which these security interests are indeed shared, however, has been called into question by some commentators who have pointed out that while the EU and China may share an "almost identical terminology [...], both sides differ in their connotation of this terminology, as well as in their (often competing) interests" (Stumbaum 2011, pp. 13-14).

The field of counterterrorism is a prime example of an issue area in which an apparently shared security interest hides profound normative and cognitive differences. In Chinese political discourse, the issue is usually approached as part of the "three evils" of separatism, extremism and terrorism, which are inextricably linked together in the approach taken by the Shanghai Cooperation Organization (SCO), for example, through the Shanghai Convention on Combating Terrorism, Separatism and Extremism (Duchatel and Ekman 2015, p. 1; Stumbaum 2007, p. 358). The connection between terrorism and separatism is another aspect of the Chinese government's primary concern for territorial integrity, and it is clearly visible with regard to the independence movements in Xinjiang, where human rights organizations have blamed Beijing of using the counterterrorism agenda to suppress the rights of Uighur minorities (cf. Human Rights Watch 2006). The European Union, on the other hand, considers separatism as a distinct issue, and unlike China it also views terrorism as a threat to fundamental values such as freedom of expression. By contrast, a CCP-run newspaper for example took the 2015 terrorist attacks against Charlie Hebdo as an opportunity to condemn what it presented as an extreme interpretation of free speech in France, also drawing parallels with the negative ways in which China is sometimes depicted in European media (Global Times 2015; cf. Duchatel and Ekman 2015, pp. 1-2).

\section{Sovereignty, Non-interference and the Use of Force}

As a result of their respective histories, the European Union and China maintain very different positions on the idea of state sovereignty. This difference holds a particular significance in the field of international security, as it has natural implications for the way Brussels and Beijing approach key themes such as the principle of non-interference and the use of force in international relations. The notion of sovereignty originated historically in Europe and it is traditionally traced to the Peace of Westphalia, although not without significant debate and disagreements (see e.g. Osiander 2001). It was paradoxically through European colonialism that the idea of state sovereignty spread outside Europe, and particularly to China. In fact, it was Europe's own violations of China's sovereign prerogatives during the 
"Century of Humiliation" which gave the notion of sovereignty the key role that it holds even to this day in Chinese political discourse. While Europe has achieved lasting peace by limiting national sovereignty and pooling it together at a supranational level, in China state sovereignty is viewed as a prized historical conquest and as a bulwark against foreign interference and oppression.

Beijing's perspective on sovereignty is formally enshrined in the Five Principles of Peaceful Coexistence formulated by Zhou Enlai and Jawaharlal Nehru in the 1954 Agreement on Trade and Intercourse between the Tibet region of China and India, which later became a cornerstone of the Non-Aligned Movement at the 1955 Bandung Conference and are still a major pillar of Chinese foreign policy today. The Five Principles are generally enunciated as follows:

1. Mutual respect for each other's territorial integrity and sovereignty.

2. Mutual non-aggression.

3. Mutual non-interference in each other's internal affairs.

4. Equality and cooperation for mutual benefit.

5. Peaceful co-existence.

The adoption of these principles by the Non-Aligned Movement under China's and India's leadership is easily understandable bearing in mind that they are meant as a foundation for the peaceful relations of states "especially if they belong to different ideological and/or systemic camps" (Wacker 2007, p. 209). It is also significant that a reference to the Five Principles was included in all the agreements concluded by China and several European states in the 1970s for the establishment of diplomatic relations.

While the European Union is often regarded as a "post-Westphalian or postsovereign polity" (Keukeleire and Delreux 2014, p. 288), China views sovereignty as an absolute and fundamental principle of international relations. From this point of view, China's position represents a more conservative and "fundamentalist" interpretation of sovereignty, retaining "the original meaning of the concept" and thus in line with traditional understandings of the rules of interaction between states. The European conceptualization of sovereignty, on the other hand, can be viewed as "reformist" or even revisionist, viewing sovereignty as subordinate to the fulfilment of state responsibilities and employing it pragmatically "as an optional tool both within and outside Europe" (Pan 2010, p. 236). In this sense China represents the norm rather than the exception in international relations, whereas Europe can be seen as the main advocate of a more progressive interpretation of sovereignty as a cardinal principle of global politics.

China's staunch defence of sovereignty is in fact in line with the position of other great powers such as the United States. Just like their counterparts in Washington, Chinese authorities are "very strict in defending their sovereignty against interference from other countries or from international institutions" (Wacker 2007, p. 209). Unlike the United States, however, China's position is based on the idea of mutuality, which is clearly a central concept in the formulation of the Five Principles of Peaceful Coexistence. Whereas Washington has generally been ready to intervene in foreign countries and interfere in their "domestic" affairs, China has 
always advocated the principle of non-intervention. While Western powers often portray this as a reluctance to accept the responsibilities which are normally attached to China's growing role in the international community, and as a refusal to protect universal values, "this choice is precisely considered in China as a 'value' and as a sign that China respects its partner countries and treats them as equal" (Keukeleire and Delreux 2014, p. 289). Naturally, Beijing's "absolutist" support for the principle of state sovereignty is also predicated on the "hope of receiving reciprocal respect for China's sovereignty concerns from others" (Pan 2010, p. 236).

China's adherence to a traditional view of sovereignty translates into an opposition to foreign intervention and to the use of force in international relations, in full respect of the principle of mutual non-interference in other countries' domestic affairs. This, however, does not necessarily imply a peaceful international stance, especially towards China's neighbours. The white paper on China's peaceful development identifies China's "core interests" as including "state sovereignty, national security, territorial integrity and national reunification" (State Council of the People's Republic of China 2011). While China's sovereignty over Tibet, Xinjiang and Taiwan is widely accepted by the international community, Beijing's quest for "territorial integrity and national reunification" also extends to other disputed areas, such as the islands of the South China Sea and their surrounding waters.

Chinese authorities have often proclaimed their intention to settle these disputes peacefully and have taken several important steps to promote regional cooperation in the area, for example by joining ASEAN's Treaty of Amity and Cooperation (TAC) in 2003. Nevertheless, China's claims to sovereignty over the South China Sea and its military presence in the area have given rise to a "security dilemma" for other littoral states, "encouraging them to strengthen their military capabilities in turn" and forcing them "to hedge against China's random use of force" (Odgaard 2012, pp. 92-93 and 100). The many incidents involving Chinese armed forces in the region have gone hand in hand with China's attempts to build a blue-water navy, for example, by establishing a large submarine base on the island of Hainan and pressing forward on its aircraft carrier programme, which has culminated so far in the acquisition and retrofitting of the former Soviet carrier Varyag, renamed Liaoning and commissioned into the PLA Navy in 2012. These sorts of actions have been interpreted by foreign commentators as "examples of the assertion of Chinese interests in the years since the financial crisis with the development of a form of "triumphalism" in Chinese policy" (Breslin 2013, p. 623).

China's insistence on the value of state sovereignty can, therefore, be seen to have an ambiguous effect on its position on matters of international security. On the one hand, it can result in Beijing taking a more aggressive stance when its own sovereignty and territorial integrity are at stake. On the other hand, it also implies that China is wary of interference in third countries' domestic affairs, whether in the form of military intervention or even simply of political conditionality. China's support for non-interference has, however, been moderated by its ambitions for great power status and by the realization of the increasingly important role that Beijing is called to play in the international community, in line with China's own growth and development. This is reflected for example in China's growing 
contribution to UN peacekeeping operations since the late 1980s. Among the permanent members of the UN Security Council, China has become the main provider of peacekeeping personnel, although mainly in technical roles, and even voted in favour of the 2005 World Summit Outcome Resolution (A/RES/60/1) at the UN General Assembly, endorsing the principle of the "responsibility to protect" (Wacker 2007, p. 210).

Despite this increasing openness, however, Beijing is still very reluctant to adopt sanctions which may pave the way for military intervention, and it has consistently insisted on the principle that the assent of all involved parties is a necessary precondition for peacekeeping operations. Even on the responsibility to protect, China has been very careful to take a moderate position in its official statements, clarifying that "the protection of the citizens ultimately depends on the government of the state concerned" and that "there must not be any wavering over the principles of respecting state sovereignty and non-interference", limiting the application of R2P only to the most serious cases of "genocide, war crime, ethnic cleansing and crimes against humanity" and making a clear distinction between R2P and humanitarian intervention (Liu 2009). By contrast, the European Union is much "more prepared than China to interfere in domestic affairs" of both its own member states and third countries, having set "the promotion of democracy, good governance and the rule of law as one of its policy objectives". The EU can, however, find some common ground with China in its own reluctance to employ military force, whether it would be attributed to relative military weakness or to the very structure and nature of the European polity (Wacker 2007, p. 211).

Europe and China's different positions on sovereignty and non-interference played a significant role in their cooperation on one of the most sensitive global security threats faced by the great powers in recent years, namely the prevention of nuclear proliferation in the Islamic Republic of Iran. As Iran's top trading partner and one of its most important allies, China was unquestionably in a key position to influence Tehran on nuclear non-proliferation. Europe, on the other hand, has been in a position of leadership on the Iran nuclear dossier ever since the E3 (France, Germany and the United Kingdom) took the initiative to engage Tehran diplomatically in 2003, leading to the Tehran Declaration of 2003 and the Paris Agreement of 2004, in which Iran agreed to suspend its uranium enrichment activities. After the election of Mahmoud Ahmadinejad as president of Iran in 2005 and the following resumption of the country's nuclear programme, China joined the diplomatic efforts of the E3 together with the United States and Russia, hence the E3+3, also referred to as P5+1 (the five permanent members of the UN Security Council plus Germany).

In this context, China has traditionally been opposed to the imposition of sanctions advocated by its Western partners. While China's position has sometimes been attributed to its commercial interests with Iran (China is the largest importer of Iranian oil), EU officials also stress the importance of China's cultural principles in its opposition to foreign interference, based on the belief that imposing strong sanctions on Iran might create a precedent which could be used against China itself in the future. ${ }^{2}$ The EU and the US have had a mixed record in pressuring China to

\footnotetext{
2 Author's interview with an EU official, Brussels, 24 July 2013.
} 
agree to sanctions against Iran. China's vote in favour of the new sanctions at the UN in 2010 was seen by analysts as 'a major success' of European and American diplomacy (Vaïsse and Kundnani 2011, p. 36). However, in 2012 Beijing openly criticized the EU for the imposition of unilateral sanctions in the form of an oil embargo, which it described as a way to intensify confrontation (Vaïsse and Dennison 2013, p. 35). Nevertheless, European officials believe that Beijing probably recognized the impact of the 2012 sanctions on Iran's elections and on its willingness to resume diplomatic negotiations. One of the most important elements for the success of the 2012 sanctions was the fact that Washington also imposed sanctions on countries which continued to import oil from Iran, a factor which led China to scale down its reliance on Iranian oil to avoid repercussions on its trade relations with the US. ${ }^{3}$ An interim agreement between Iran and the E3+3 was reached in November 2013, establishing limitations to Iran's nuclear programme in exchange for a partial lifting of Western sanctions. After further intense negotiations, in July 2015 the E3+3 and Iran brokered a final agreement, known as the Joint Comprehensive Plan of Action, which should 'effectively block Iran's multiple pathways to a nuclear weapon for the next 15 years' (Bohlen 2015, p. 60).

\section{Multilateralism and Multipolarity}

The differences between European and Chinese approaches to international security are also visible in the multilateralism/multipolarity dichotomy. These two notions, although apparently similar and sometimes used interchangeably, are in fact entirely distinct and unrelated to each other. Multipolarity describes a de facto "distribution of (economic, political and military) power" (Wacker 2007, p. 213) among the main actors of the international arena, implying "the emergence of new poles in the third world" (Odgaard and Biscop 2007, p. 68) and "a world order where countries balance against the prevailing power" (Zhao 2008, p. 38). Multilateralism, on the other hand, is "a process; a way of acting that involves several states (big, medium or small) working together as a matter of practice" (Scott 2013, p. 31) and "on the basis of generalised principles of conduct" (Ruggie 1993a, p. 14), normally relying on institutionalized forms of cooperation.

While the European Union is a prime example of multilateralism, as well as one of its staunchest advocates in international relations, the notion of multilateralism has entered China's political discourse only in relatively recent times. In fact, for most of its history the leaders of the People's Republic "stressed the importance of bilateralism and were reluctant to endorse multilateralism because of China's concern over possible erosion of national sovereignty" (Zhao 2008, p. 37). Even the more recent embrace of multilateralism on the part of Beijing "masks a divergence between a normative (values) EU use of multilateralism terminology versus a more instrumental PRC use of multilateralism terminology" (Scott 2013, p. 31). It could be argued that in many ways China's leaders have simply come to the realization that multilateralism may be a more effective and acceptable way of pursuing the

\footnotetext{
3 Ibid.
} 
anti-hegemonic goals which they traditionally sought to achieve through the construction of a multipolar world order.

The rhetoric of multipolarity has appeared prominently in China's political discourse since the end of the Cold War, and it is a cornerstone of Beijing's view of international politics, especially in the realm of high politics and security relations. Being counted as a pole within a multipolar international structure is one of China's fundamental foreign policy objectives, and it is clearly related to its desire to assert its sovereignty and independence in the face of foreign interference. Deng Xiaoping expressed this goal clearly when he commented on the end of the Cold War's bipolarity, stating that "in future when the world becomes three-polar, four-polar or five-polar, the Soviet Union [...] will still be one pole. In the so-called multi-polar world, China too will be a pole. We should not belittle our own importance: one way or another, China will be counted as a pole" (Deng 1990).

A later official document lists the goals that Beijing seeks to attain through multipolarity in clearly normative terms, claiming that "multi-polarization on the whole helps weaken and curb hegemonism and power politics, serves to bring about a just and equitable new international political and economic order and contributes to world peace and development" (Ministry of Foreign Affairs of the PRC 2004). In addition to presenting multipolarization as an inevitable historical process, the document also implicitly clarifies that it is seen by China essentially in an antiAmerican key: "At present [...] an individual country is pursuing a new 'gunboat policy' in contravention of the United Nations Charter and the universally acknowledged principles governing international relations in an attempt to establish a monopolar world under its guidance. This is against the tide of history and is doomed to failure. [...] China is firmly opposed any form of hegemonism and power politics [sic]. China is ready, together with the international community, to safeguard world peace and stability and make joint efforts to bring about a just and equitable new international political and economic order" (Ministry of Foreign Affairs of the PRC 2004). From China's point of view, the discourse of multipolarity resonates with the anti-hegemonic rhetoric of the "Century of Humiliation" and it reinforces its defence of the principle of non-interference, weaving together concerns for international security and stability with a claim for justice and equity in global affairs.

Multipolarity is mentioned sometimes by individual EU member states, most prominently France (Wacker 2007, p. 213), and it even finds its place in the official rhetoric of the European Union, especially with reference to its relations with partners such as China (Scott 2013, pp. 35-36). However, the notion of multipolarity is noticeably absent from the 2003 European Security Strategy, which on the other hand makes it clear that Europe's "security and prosperity increasingly depend on an effective multilateral system" (Council of the European Union 2003). A 2010 speech by Commission President Barroso on multilateral global governance recognizes the merit of multipolarity insofar as "it limits 'hegemonic power', which can often be a source of instability". At the same time, it also recognizes "the risks associated with multipolarity" and "violent competition between great powers", and it portrays multilateralism as "the right mechanism to build order and governance in a multipolar world". In this view, multipolarity is 
seen as a potentially necessary condition for multilateralism, but whereas "the global balance of power may limit hegemonic unilateralism, [..] it does not by itself stop unilateral strategies by the different poles". Multilateralism is seen as a fundamental value of the European Union, a modus operandi which has been firmly established on the European continent and which the EU must endeavour to transfer onto the world stage to avoid the dangers of "multipolar power politics" (Barroso 2010). The promotion of "an international system based on stronger multilateral cooperation" is in fact a "constitutional goal" of the Union, enshrined in Article 21.2(h) of the Treaty on European Union.

Whereas the European Union views multilateralism as both a means and an end in its foreign policy doctrine (Lazarou et al. 2010, p. 20), China's "turn to multilateralism" (Wu and Lansdowne 2008, p. 3; cf. also Klein et al. 2010, p. 24) only began hesitantly in the 1990s, mainly with the aim of "promoting 'multipolarization' in an attempt to counter U.S. preponderance rather than adopting multilateralism per se" (Zhao 2008, p. 38). In the course of the first decade of the century, however, under Hu Jintao's leadership, the People's Republic appears to have embraced multilateralism more enthusiastically, with a corresponding decline of the use of the term "multipolarity" in the government's official discourse (Song 2010, pp. 770-771; Scott 2013, p. 38). China's involvement in multilateral arrangements has mainly been focused on the economic arena, for example through Beijing's participation in the WTO and ASEAN+3, but it has gradually expanded to the field of international security as well (Wu and Lansdowne 2008 , p. 3). China, for example, was one of the leading founders of the Shanghai Five in 1996 (later to become the Shanghai Cooperation Organization in 2001) and it has become increasingly involved in regional multilateral security arrangements.

China's commitment to multilateralism, however, is generally called into question by most observers, who often feel the need to qualify Beijing's version of multilateralism with adjectives such as "selective" (Wu and Lansdowne 2008, p. 8; Song 2010, p. 771; Shambaugh 2011, p. 17), "practical" or "strategic" (Klein et al. 2010, pp. 24-26). China has shown a particular preference for those multilateral settings in which it can best protect its national interest, such as the UN Security Council, where it enjoys veto power, as well as a particular position as the sole representative of developing, culturally non-European and non-democratic or protodemocratic states (Wu and Lansdowne 2008, p. 6). While Beijing has accepted to be restrained by multilateral rules, such as those prescribed by international nonproliferation regimes, it has only done so out of the realization that these arrangements best guarantee its own security by prohibiting neighbours such as Japan and Taiwan from ever acquiring nuclear weapons (Zhao 2008, p. 38). Chinese leaders have also been opposed to the use of multilateral settings, such as ASEAN or the ASEAN Regional Forum, to discuss core interests such as territorial sovereignty over the South China Sea (Scott 2013, p. 39; cf. Pawlak 2014, pp. 102-103).

The notion of multilateralism has become firmly embedded in the rhetoric of EU-China relations, becoming a staple element of EU-China Summit declarations. At first the discourse was limited only to references to multilateral trade (China-EU 2001) but it quickly expanded to the field of international security to include references to "multilateral non-proliferation, arms control and disarmament" 
(China-EU 2002), the need for a multilateral approach to the fight against terrorism (China-EU 2003), and to post-conflict reconstruction in cases such as Iraq (ChinaEU 2004). Most joint summit declarations since then have included references to such notions as a "strong support for a fair, just and rules-based multilateral international system with the UN playing a central role" (China-EU 2006) and "effective multilateralism" (China-EU 2007). The chapter on "Peace and Security" of the EU-China 2020 strategic agenda for cooperation (China-EU 2013, p. 3), while recognizing the reality of a multipolar world, describes multilateralism as "crucial to ensure effective, coordinated and coherent responses to pressing global challenges".

The extent to which this similarity in European and Chinese discourses may be indicative of a true normative convergence is dubious, and contested at best. While some commentators appear more inclined to underline the evolution of China's foreign policy discourse towards an increasingly multilateral stance (e.g. Song 2010), others stress how bilateralism remains nevertheless China's "central diplomatic approach" (Klein et al. 2010, p. 39). Overall, China's approach to multilateralism seems motivated by a number of concerns such as anti-hegemonism, economic development and international image (cf. Wu and Lansdowne 2008, pp. 9-11), but it remains too soon to assess the extent to which Chinese leaders may have moved in the direction of a genuinely normative multilateralism (Scott 2013, p. 43).

The divergence between the EU and China on the intrinsic value of multilateral institutions is clearly visible in the case of one of Europe's most significant foreign policy goals in the field of nuclear non-proliferation, namely the entry into force of the Comprehensive Nuclear Test-Ban Treaty (CTBT). The entry into force of the CTBT is conditional upon its ratification by 44 specific countries listed in Annex 2, and as of 2016 eight of these countries have yet to ratify the agreement: China, Egypt, Iran, Israel, and the United States, which have signed the Treaty, and North Korea, India, and Pakistan, which have not yet signed it. All EU member states have ratified the treaty and the EU has been one of its staunchest supporters. The EU has also provided "significant financial backing towards the built-up [sic] of its extensive global monitoring infrastructure and its international secretariat", and therefore, it has a "substantial interest in pushing forward the CTBT process" (Mergenthaler 2015, p. 134).

China's ratification of the CTBT is one of the main priorities of Europe's cooperation with Beijing in the field of nuclear non-proliferation, and the EU makes regular demarches to all of the eight Annex 2 countries which have yet to ratify the treaty. China's position since joining the CTBT is that it is committed to a voluntary moratorium on nuclear testing, and China has abstained from performing nuclear tests since 1996, making it "a de facto participant in the regime" (Gill 2007, p. 86). While other nuclear powers have also accepted this voluntary moratorium pending the entry into force of the CTBT, it has been noted that "China has the smallest strategic nuclear arsenal and the smallest testing program, so its willingness to sign on to and abide by the CTBT is significant" (Gill 2007, p. 95). The Chinese position on this front is highly influenced by the actions of the United States, as Beijing is adamant on not ratifying the treaty before Washington does. EU officials would 
seem to pursue this goal in a constructive manner through the existing dialogue mechanism, trying to put themselves "in China's shoes to find the right arguments". 4 For example, the EU has pointed out that it would be in China's own interest to ratify the CTBT before the US, instead of doing so as a reaction to Washington's decisions, as it would strengthen China's image as a global leader in nuclear non-proliferation. ${ }^{5}$ Nevertheless, the United States appears to remain an unavoidable factor in China's decision-making on CTBT ratification. According to Chinese experts and former military officers, China stands to lose much more than the US from the CTBT, as halting its testing programme would lock Beijing in a "lower place on the nuclear learning curve" compared to Washington. While the US has conducted over 1000 nuclear tests, China has only performed 45 tests to date: "needing more tests to ensure reliability of its nuclear arsenal, China has no incentive to ratify before the United States does so" (Fitzpatrick 2013).

On the other hand, it is also possible to identify cases in which the EU and China managed to find a convergence of views on a multilateral approach to global security, resulting in positive cooperation between these two major actors. The multilateral anti-piracy operations in the Gulf of Aden and off the coast of Somalia constitute a particularly noteworthy case of EU-China cooperation on a UNmandated mission. These represented for both the EU and China "their first modern overseas maritime operations" (Larik and Weiler 2011, p. 82): for Beijing, it constituted "the first overseas deployment for Chinese maritime forces since the fifteenth century" expeditions of Admiral Zheng He's Treasure Fleet (Yan 2008); for the EU, EUNAVFOR Atalanta represented "its first ever naval operation under its Common Security and Defence Policy" (Kamerling and van der Putten 2011, p. 178). Both China and the EU share strikingly similar interests in the fight against piracy in the region. On the one hand, they both have clear economic interests in guaranteeing the safety of the naval routes concerned by the pirates' attacks (Helly 2009, pp. 393-394; Kamerling and van der Putten 2011, pp. 182-184; Larik and Weiler 2011, pp. 85-86). On the other hand, they also share the goal of being perceived-both domestically and internationally-as great powers capable of shouldering global responsibilities and conducting effective naval operations to defend their interests and those of the international community (Larik and Weiler 2011, pp. 87-89).

While they may share similar goals, however, the EU and China have pursued very different approaches in their anti-piracy operations, which is indicative of persisting normative and cultural differences between Brussels and Beijing. The European approach has been described as based on a "comprehensive understanding of security", taking into account "the interlocking of different threats and the need to employ military, as well as civilian means using multilateral institutions and acting in conformity with the rule of law" (Larik and Weiler 2011, p. 90). Accordingly, the EU has focused on the importance of due process and human rights in the treatment of captured piracy suspects, supporting the Transitional Federal Government and since 2012 the Federal Government of Somalia (cf. Balthasar

\footnotetext{
${ }^{4}$ Author's interview with an EU official, Brussels, 8 July 2013.

${ }^{5}$ Ibid.
} 
2014 , p. 2) and promoting multilateral cooperation by co-chairing the regular Shared Awareness and Deconfliction (SHADE) meetings among stakeholders and contributors of naval forces.

The Chinese approach, on the other hand, seemed rather limited to escort missions, avoiding as much as possible any interference in what Beijing perceives as internal affairs of the federal government in Mogadishu, and upholding China's views on the foremost importance of state sovereignty. Chinese leaders were also initially reluctant to join in multilateral coordination efforts through SHADE, which was perceived as a US-led initiative, and rather advocated a stronger coordination role for the UN or a geographical division of the Gulf of Aden into sectors of responsibility for each contributor of naval forces (Larik and Weiler 2011, p. 95). Eventually China agreed to join SHADE in 2010, following EU mediation efforts underlining the fact that SHADE coordination had an entirely non-binding and voluntary nature, and as such it would not place Chinese forces under any foreign authority (Larik and Weiler 2011, pp. 95-96; cf. Erikson and Strange 2013).

\section{Concluding Remarks}

This article attempted to provide an answer to the puzzle of how to account for the variations in levels and effectiveness of security cooperation between the EU and China, particularly given the apparently structural nature of the main factors affecting their security relationship. The hypothesis put forward in this study was that normative differences and overlaps could hold explanatory value in this regard, on the basis of theoretical premises grounded in social constructivism. To this purpose, the article contributed a detailed discussion of the normative positions held, respectively, by the EU and China, particularly with regard to definitions of threats and priorities, positions on national sovereignty and non-interference, and views on multilateralism and multipolarity. The impact of these normative positions was illustrated and discussed with reference to some salient cases of EU-China security cooperation, such as the Iranian nuclear issue, the ratification of the CTBT, and anti-piracy operations in the Gulf of Aden. Examining EU-China security cooperation in its full extent is obviously beyond the limited scope of this article, and it should be the object of a much larger research project. But these cases are certainly noteworthy in light of their salience and insofar as they allow to draw some significant conclusions on the role of normative differences and overlaps, the interplay between norms and interests, as well as their interaction with some of the factors identified in the beginning of the article-particularly the role of the United States as the main security actor in international affairs.

In the case of the Iranian nuclear issue, it was noted how interests and norms both played a role in explaining China's reluctance to the imposition of harsh sanctions on Tehran. Interests and norms reinforced each other, creating obstacles to cooperation between China and the West, and it was ultimately China's interest in its trade relations with the United States that led Beijing to accept a cooperative stance on economic sanctions. The case of China's ratification of the CTBT, on the other hand, is exemplary of the difference between Europe's views on 
multilateralism and China's more pragmatic stance on multipolarity. It also shows how this normative difference is affected by one of the structural factors addressed at the outset of this article, namely the role of the United States: Beijing's de facto support for the CTBT multilateral regime is constrained de jure by its concerns for the hegemonic role of the US, which resonate with China's views on multipolarity. A similar dynamic is also noticeable in the case of EU-China cooperation on antipiracy operations in the Gulf of Aden, and particularly with respect to China's participation in the multilateral coordination efforts pursued through the SHADE mechanism. China's initial reluctance to participate in this framework was explained with reference to its perception as a US-hegemonic initiative, and therefore, contrary to China's normative position on multipolarity and national sovereignty. The EU was only able to convince Beijing to join the multilateral mechanism after mediation efforts aimed at underlining its compatibility with China's views of the international order.

The cases presented in this article support the notion that normative differences and overlaps play a role in understanding EU-China security cooperation, but at the same time they also clear the field from any temptation of normative reductionism. Normative differences contribute to explaining China's reluctance to fully engage with the EU in the cases taken into account, and some of the most successful cases of cooperation - such as in SHADE-were only possible once framed in terms which were compatible which China's worldviews. At the same time, however, material and strategic interests were also a crucial variable in conjunction with ideational factors, often in ways which can be usefully interpreted in terms of the dynamics of "recursive interaction" explored by McSweeney. China's normative position on multipolarity can only be fully understood in its recursive interaction with China's anti-hegemonic interest in containing Washington's predominance in international security. Similarly, Beijing's position on the Iranian nuclear programme indicates that the best way to understand China's norms on sovereignty and non-interference is in a recursive interaction with its interest to maintain a strong independence from foreign powers, itself a result of China's history. Norms and interests reinforce each other. The success of EU-China cooperation on international security depends crucially on policymakers' ability to engage both of these dimensions.

Open Access This article is distributed under the terms of the Creative Commons Attribution 4.0 International License (http://creativecommons.org/licenses/by/4.0/), which permits unrestricted use, distribution, and reproduction in any medium, provided you give appropriate credit to the original author(s) and the source, provide a link to the Creative Commons license, and indicate if changes were made.

\section{References}

Balthasar, Dominik. 2014. Somalia's federal agenda: From fragility to fragmentation? Brief Issue 17. Paris: European Union Institute for Security Studies.

Barroso, José. 2010. The European Union and multilateral global governance. Speech delivered at a conference at the European University Institute, Florence, 18 June 2010. SPEECH/10/322.

Bohlen, Avis. 2015. Iran: An opening for diplomacy? Survival 57 (5): 59-66. 
Bräuner, Olivier. 2014. Think small: How to improve China-EU security cooperation. In EU-China: The next ten years, ed. Shada Islam, and Patricia Diaz, 101-103. Brussels: Friends of Europe.

Breslin, Shaun. 2013. China and the global order: Signalling threat or friendship? International Affairs 89 (3): 615-634.

Buzan, Barry. 1983. People, states, and fear: The national security problem in international relations. Brighton: Wheatsheaf.

Campbell, Kurt, and Brian Andrews. 2013. Explaining the US "pivot" to Asia. Americas 2013/01. London: Chatham House.

Carr, Edward. 1939. The twenty years' crisis, 1919-1939: An introduction to the study of international relations. London: Macmillan.

China-EU. 2001. Joint press statement at the 4th China-EU Summit, Brussels, 5 September 2001.

China-EU. 2002. Joint press statement at the 5th China-EU Summit, Copenhagen, 24 September 2002.

China-EU. 2003. Joint press statement at the 6th China-EU Summit, Beijing, 30 October 2003.

China-EU. 2004. Joint press statement at the 7th China-EU Summit, The Hague, 8 December 2004.

China-EU. 2006. Joint press statement at the 9th China-EU Summit, Helsinki, 9 September 2006.

China-EU. 2007. Joint press statement at the 10th China-EU Summit, Beijing, 28 November 2007.

China-EU. 2013. EU China 2020 strategic agenda for cooperation. Document adopted at the 16th ChinaEU Summit, Beijing, 21 November 2013.

Clinton, David. 1986. The national interest: normative foundations. The Review of Politics 48 (4): 495-519.

Council of the European Union. 2003. A secure Europe in a better world: European security strategy, Brussels: EU institution.

Deng, Xiaoping. 1990. The international situation and economic problems. In Selected works of Deng Xiaoping. http://www.people.com.cn/english/dengxp/home.html. Accessed 29 April 2016.

Duchatel, Mathieu, and Alice Ekman. 2015. Countering terrorism: An area for EU-China cooperation? Brief Issue. Paris: European Union Institute for Security Studies.

Erikson, Andrew, and Austin, Strange. 2013. China and the international antipiracy effort. The Diplomat. 1 November 2013.

European Commission. 1994. Towards a new Asian strategy. Communication from the Commission. Brussels. COM (1994) 314 final.

European Commission. 1995. A long term policy for China-Europe relations. Communication from the Commission. Brussels. COM (1995) 279 final.

Finamore, Salvatore. 2014. Norms, instruments and strategy: Comparing EU and US engagements of China. In The EU, the US and China: Towards a new international order?, ed. Jing Men, and Wei Shen, 106-125. Cheltenham: Edward Elgar.

Fitzpatrick, Mark. 2013. Why China will wait on nuclear test ban ratification. Politics and Strategy: The Survival Editors' Blog. 28 October 2013.

Gill, Bates. 2007. Rising star: China's new security diplomacy. Washington: Brookings.

Gill, Bates. 2010. Managing tensions and promoting cooperation: US-Europe approaches on security issues with China. In US-China-EU relations: Managing the new world order, ed. Robert Ross, Øystein Tunsjø, and Zhang Tuosheng, 259-282. London: Routledge.

Global Times. 2015. Free speech mania may intensify clashes. 19 January 2015.

Helly, Damien. 2009. EUNAVFOR Somalia. In European Security and Defence Policy: The first ten years (1999-2009), ed. Giovanni Grevi, Damien Helly, and Daniel Keohane, 391-402. Paris: European Union Institute for Security Studies.

Howorth, Jolyon. 2012. Decision-making in security and defense policy: Towards supranational intergovernmentalism? Cooperation and Conflict 47 (4): 433-453.

Human Rights Watch. 2006. Eurasia: uphold human rights in combating terrorism. New York, 14 June 2006.

Kamerling, Susanne, and Frans-Paul van der Putten. 2011. Europe sails East, China sails West: Somali piracy and shifting geopolitical relations in the Indian Ocean. In China, Europe and international security, ed. Frans Paul van der Putten, and Chu Shulong, 178-194. London: Routledge.

Keukeleire, Stephan, and Tom Delreux. 2014. The foreign policy of the European Union, 2nd ed. Basingstoke: Palgrave Macmillan.

Klein, Nadia, Wulf, Reiners, Chen, Zhimin, Jian, Junbo, and Ivo, Šlosarčík. 2010. Diplomatic strategies of major powers: Competing patterns of international relations? The cases of the United States of America, China and the European Union. MERCURY E-paper no. 2. 
Larik, Joris, and Quentin Weiler. 2011. Going naval in troubled waters: The EU, China and the fight against piracy off the coast of Somalia. In China and the European Union in Africa: Partners or competitors, ed. Jing Men, and Benjamin Barton, 81-103. Farnham: Ashgate.

Lazarou, Elena, Geoffrey, Edwards, Christopher, Hill, and Julie, Smith. 2010. The evolving "doctrine" of multilateralism in the 21st century. MERCURY E-paper no. 3.

$\mathrm{Li}$, Chen, and Lucy, Xu. 2014. Chinese enthusiasm and American cynicism: The "new type of great power relations". China-US Focus, 4 December 2014.

Liu, Zhenmin. 2009. Statement by Ambassador Liu Zhenmin at the Plenary Session of the General Assembly on the question of responsibility to protect. New York: Permanent Mission of the People's Republic of China to the United Nations.

McSweeney, Bill. 1999. Security, identity and interests: A sociology of international relations. Cambridge: Cambridge University Press.

Mergenthaler, Stephan. 2015. Managing global challenges: The European Union, China and EU network diplomacy. Wiesbaden: Springer.

Ministry of Foreign Affairs of the People's Republic of China. 2002. China's position paper on the new security concept, Beijing.

Ministry of Foreign Affairs of the People's Republic of China. 2004. China's views on the development of multipolarization, Beijing.

Ministry of Foreign Affairs of the People's Republic of China. 2014. China's policy paper on the EU: Deepen the China-EU comprehensive strategic partnership for mutual benefit and win-win cooperation, Beijing.

Norheim-Martinsen, Per. 2010. Beyond intergovernmentalism: European security and defence policy and the governance approach. Journal of Common Market Studies 48 (5): 1351-1365.

Odgaard, Liselotte. 2012. China and coexistence: Beijing's national security strategy for the twenty-first century. Baltimore: Johns Hopkins University Press.

Odgaard, Liselotte, and Sven Biscop. 2007. The EU and China: Partners in effective multilateralism? In The international politics of EU-China relations, ed. David Kerr, and Liu Fei, 54-77. Oxford: Oxford University Press.

Osiander, Andreas. 2001. Sovereignty, International Relations, and the Westphalian myth. International Organization 55 (2): 251-287.

Pan, Zhongqi. 2010. Managing the conceptual gap on sovereignty in China-EU relations. Asia Europe Journal 8 (2): 227-243.

Pawlak, Patryk. 2014. Chinese network diplomacy as a challenge for transatlantic partners. Asia Europe Journal 12 (1): 95-108.

Perlo-Freeman, Sam, Aude Fleurant, Pieter Wezeman, and Siemon Wezeman. 2015. Trends in world military expenditure, 2014. SIPRI Fact Sheet.. Stockholm: Stockholm International Peace Research Institute.

Ruggie, John Gerard. 1993a. Multilateralism: The anatomy of an institution. In Multilateralism matters: The theory and praxis of an institutional form, ed. John Gerard Ruggie, 3-48. New York: Columbia University Press.

Ruggie, John Gerard. 1993b. Territoriality and beyond: Problematizing modernity in international relations. International Organization 47 (1): 139-174.

Scott, David. 2013. Multipolarity, multilateralism and beyond...? EU-China understandings of the international system. International Relations 27 (1): 30-51.

Segal, Gerald. 1999. Does China matter? Foreign Affairs 78 (5): 24-36.

Shambaugh, David. 2011. Coping with a conflicted China. The Washington Quarterly 34 (1): 7-27.

Sjursen, Helene. 2004. Security and defence. In Contemporary European foreign policy, ed. Walter Carlsnaes, Helene Sjursen, and Brian White, 59-74. London: Sage.

Sjursen, Helene. 2011. Not so intergovernmental after all? On democracy and integration in European foreign and security policy. Journal of European Public Policy 18 (8): 1078-1095.

Song, Xinning. 2010. European "models" and their implications to China: Internal and external perspectives. Review of International Studies 36 (3): 755-775.

Song, Xinning. 2013. Security and the role of China. In The Palgrave handbook of EU-Asia relations, ed. Thomas Christiansen, Emil Kirchner and Philomena Murray, 471-480. Basingstoke: Palgrave Macmillan.

State Council of the People's Republic of China. 2011. White paper on China's peaceful development, Beijing. 
Stumbaum, May-Britt. 2007. Opportunities and limits of EU-China security cooperation. The International Spectator 42 (3): 351-370.

Stumbaum, May-Britt. 2011. Europe's views on China's role in international security. In China, Europe and international security, ed. Frans Paul van der Putten, and Chu Shulong, 7-19. London: Routledge.

Vaïsse, Justin, and Susi Dennison. 2013. European foreign policy scorecard 2013. London: European Council on Foreign Relations.

Vaïsse, Justin, and Hans Kundnani. 2011. European foreign policy scorecard 2010. London: European Council on Foreign Relations.

Wacker, Gudrun. 2007. Similarities and differences. In China-EU: A common future, ed. Stanley Crossick, and Etienne Reuter, 207-214. Singapore: World Scientific.

Wang, Bo. 2011. Bilateral security relations between China and Europe. In China, Europe and international security, ed. Frans Paul van der Putten, and Chu Shulong, 37-62. London: Routledge.

Weldes, Jutta. 1996. Constructing national interests. European Journal of International Relations 2 (3): 275-318.

Wendt, Alexander. 1999. Social theory of international politics. Cambridge: Cambridge University Press. Wong, Reuben. 2015. China's security thinking. In EUSC Policy Paper Series.

Wu, Guoguang, and Helen Lansdowne. 2008. International multilateralism with Chinese characteristics: Attitude changes, policy imperatives, and regional impacts. In China turns to multilateralism: Foreign policy and regional security, ed. Guoguang Wu, and Helen Lansdowne, 3-18. Abingdon: Routledge.

$\mathrm{Xi}$, Jinping. 2014. New Asian security concept for new progress in security cooperation. Speech delivered at the Fourth Summit of the Conference on Interaction and Confidence Building Measures in Asia, Shanghai, 21 May 2014.

Yan, Hao. 2008. China ready to send warships to Somalia. Xinhua, 26 December 2008.

Zakaria, Fareed. 2015. Whatever happened to Obama's pivot to Asia? Washington Post, 16 April 2015.

Zhao, Suisheng. 2008. China rising: Geo-strategic thrust and diplomatic engagement. In China-US relations transformed: Perspectives and strategic interactions, ed. Suisheng Zhao, 20-42. London: Routledge.

Salvatore Finamore is a PhD graduand at the University of Cambridge, Department of Politics and International Studies, where he was also Managing Editor of the Cambridge Review of International Affairs. He holds an MA cum laude from LUISS University (Rome), and has done further studies at Renmin University of China, and at the University of Uppsala. His research focuses on foreign policy analysis and China-Europe relations, and particularly on the nature of engagement as a foreign policy strategy and on foreign policy instruments in the EU's China policy. His work has been presented at several international conferences in Europe and North America. 